\title{
АРТ-ТЕРАПЕВТИЧНА ПІДГОТОВКА ЯК СКЛАДОВА ФОРМУВАННЯ СОЦІАЛЬНОЇ ЗРІЛОСТІ КУРСАНТІВ ПОЛІЦЇ̈
}

\author{
Наталя Думко \\ викладач \\ Одеський державний університет внутрішніх справ \\ м. Одеса, Україна \\ ORCID ID 0000-00003-2044-4496 \\ ndumko@my.com
}

\begin{abstract}
Анотація. У статі розглянуто проблему особливості арт-терапевтичної підготовки майбутніх курсантів поліції з метою формування в них соціальної зрілості, обгрунтовано основи кримінального профайлінгу в їхній професійній підготовці. Методологія кримінального профайлінгу передбачає роботу з матеріалами кримінального провадження та інтерпретацію доказів. Результатом роботи профайлера $є$ кримінальний профіль - юридично значимий документ, у якому описані особистість і поведінка злочинця і жертви в ключі вчиненого злочину або серії злочинів. Сучасна парадигма профайлінгу має кілька джерел походження: дослідження кримінологів, фахівців із галузі судової медицини, психіатрів $\mathrm{i}$ кримінальних психологів.

Арт-терапія створює можливість як для занурення у хворобливі переживання, так i для актуалізації ресурсних станів, а також для трансформації та інтеграції досвіду. Застосували арт-терапію засобом переважно невербального спілкування та через образотворчу діяльність. Подальшу роботу вбачаємо в розробці педагогічних умов застосування кримінального профайлінгу на заняттях у закладах вищої освіти.
\end{abstract}

Ключові слова: арт-терапія; кримінальний профайлінг, підготовка курсантів поліції; соціальна зрілість.

Постановка проблеми в загальному вигляді. Специфіка сучасної правоохоронної діяльності вимагає від працівників органів внутрішніх справ не лише грунтовних юридичних знань, а й розвиненої педагогічної культури, сформованих умінь і навичок. У зв'язку із змінами в концепції поліцейської діяльності та зміщенням акцентів іiї на функцію соціального обслуговування населення виникла необхідність озброєння поліцейських глибокими психологічними та педагогічними знаннями, які стосуються взаємодії 3 населенням і вирішення конфліктів, методами надання психологічної допомоги при втручанні в сімейно-побутові конфлікти тощо. Для ефективної педагогічної підготовки особового складу патрульної поліції потрібно акцентувати увагу на розробці наукових основ процесу навчання (на широкому міждисциплінарному базисі), створення навчальних програм та автоматизованих навчальних систем, формалізації методів навчання, використання передового педагогічного досвіду Наявні на сьогоднішній день дослідження особистості працівника поліції в межах юридичної психології, як правило, стосуються вивчення особливостей

Професіоналізм педагога: теоретичні й методичні аспекти. - Вип. 11. - Слов’янськ, 2019. 
Арт-терапевтична підготовка як складова формування соціальної зрілості курсантів поліції

їхньої інтелектуальної сфери, надійності, стресостійкості, агресивності, здатності контролювати застосування зброї.

Аналіз останніх досліджень і публікацій. Вагомий вплив на формування соціальної зрілості курсантів поліції має його компетентність. Компетентність, як інтегральне явище, має відображення на результатах правоохоронної діяльності. Одним із важливих різновидів компетентності курсантів поліції, що впливає на ефективність професійної діяльності $€$ здоров'язбережувальна компетентність, в основі якої лежить арт-терапевтична діяльність.

Основні положення здоров'язбережувальної компетентності у своїх працях розглядали: О. Антонова, І. Анохіна, Д. Воронін, В. Горащук, В. Лозинський, А. Маркова, Л. Мітіна, О. Редькіна, Г. Серіков, М. Стригін, А. Сердюк, Н. Фомін, В. Царевський, Н. Тамарська та ін.

Використання здоров'язбережувальних технологій у роботі поліції призвело до впровадження арт-терапевтичної діяльності курсантів поліції. Засновниками арт-терапії були Г. Гід, В. Ловенфельд, Ф. Чизен та ін., які розглядали іiі як засіб розвитку емоційної сфери особистості, мислення та природної креативності.

Сучасні дослідники (Н. Горєва, В. Коропуліна, М. Смирнова та ін.) визначають арт-терапію як засіб та технологію реабілітації людей із проблемами в поведінці за допомогою мистецтва та художньо-творчої діяльності, яка будується на здібностях до образного сприйняття довкілля. В арт-терапії мистецтво - це діяльність, яка являє собою експериментування дітей із художніми образами, символами як замінників реальних об'єктів.

Проте питанням упровадження арт-терапевтичної діяльності 3 метою формування в курсантів поліції соціальної зрілості та на цій основі подальше використання методів арт-терапії в професійній діяльності приділено недостатньо уваги науковцями.

Формулювання цілей статті. Розкрити особливості арт-терапевтичної підготовки майбутніх курсантів поліції з метою формування в них соціальної зрілості, обгрунтувати основи кримінального профайлінгу в їхній професійній підготовці. Задачі дослідження: 1) розкрити особистості професійного розвитку курсантів поліції; 2) визначити й обгрунтувати основи кримінального профайлінгу; 3) показати застосування арт-терапевтичної підготовки майбутніх курсантів поліції.

Теоретичні основи дослідження. Професійний розвиток патрульного поліцейського $є$ складним довготривалим процесом, який передбачає не лише поступовий перехід від одного етапу до іншого, а й виникнення професійних криз, які $є$ накопиченням як зовнішніх, так і внутрішніх протиріч. У вітчизняній 
Арт-терапевтична підготовка як складова формування соціальної зрілості курсантів поліції

та зарубіжній психології можна умовно виділити три підходи щодо вивчення криз: 1) криза як результат зміни провідної діяльності і зміни соціальної ситуації, у співвідношенні з психічним розвитком (Л. Божович, Л. Виготський, В. Давидов, Д. Ельконін та ін.); 2) криза як внутрішнє (вроджене) прагнення особистості до розвитку, яке відбувається впродовж усього життя (Б. Лівехуд, Е. Еріксон та ін.); 3) криза як зміна детермінанти розвитку в процесі життєвого шляху особистості (Дж. Ловінгер, Р. Хавігхерст та ін.).

Профайлінг (англ. «profile» - профіль) - це поняття, що означає сукупність психологічних методів і методик оцінки та прогнозування поведінки людини на основі аналізу найбільш інформативних ознак, характеристик зовнішності, невербальної і вербальної поведінки. Спочатку термін «профайлінг» (профілювання) вживався в контексті складання пошукового психологічного портрета (профілю) невідомої особи за слідами на місці злочину. Методологія кримінального профайлінгу передбачає роботу з матеріалами кримінального провадження та інтерпретацію доказів. Результатом роботи профайлера $\epsilon$ кримінальний профіль - юридично значимий документ, у якому описані особистість і поведінка злочинця та жертви в ключі вчиненого злочину або серії злочинів. Сучасна парадигма профайлінгу має кілька джерел походження: дослідження кримінологів, фахівців із галузі судової медицини, психіатрів і кримінальних психологів. Сьогодні найбільш широко профайлінговий підхід до розслідування злочинів використовується Федеральним бюро розслідувань (FBI) у США, де існує особливий підрозділ - відділ із вивчення поведінки. Одним із напрямків діяльності цього підрозділу $є$ консультування з питань пошуку злочинців і складання профілів.

У вітчизняній науці представлена невелика кількість робіт, присвячених профайлінговим дослідженням. Процес соціальної перцепції має такі етапи:

1. Сприйняття зовнішнього вигляду і поведінки об’єкта спостереження.

2. Формування уявлень про психологічні особливості і психічний стан об'єкта спостереження.

3. Формулювання припущень про причини і наслідки поведінки.

4. Вироблення стратегії власної поведінки (Цільмак, 2011).

Сучасним профайлінгом у роботі кримінальної поліції можна вважати арттерапевтичну підготовку курсантів поліції з метою формування в них соціальної зрілості.

У науково-педагогічній літературі арт-терапія розглядається як засіб, який дозволяє піклуватися про емоційний стан і психічне здоров'я людини, групи, колективу засобами художньої діяльності (Г. Буряковський, Л. Гисневич, А. Захарова, Т. Зінкевич-Свстигнеєва та ін.). На сучасному етапі арт- 
Арт-терапевтична підготовка як складова формування соціальної зрілості курсантів поліції

терапевтична робота здійснюється у двох напрямках: перший - це арттерапевтична робота із збереження інтелекту особистості, але яка має проблеми в розвитку; другий - це арт-терапевтична допомога людям, які мають порушення інтелекту.

Термін «арт-терапія» став використовуватися в нашій країні відносно нещодавно. Як самостійний напрям у лікувально-реабілітаційної, педагогічній та соціальної роботи арт-терапія нараховує всього декілька десятиліть своєї історії. Як емпіричний метод арт-терапія почала формуватися з середини XX століття, коли отримав широку популярність і поширення досвід роботи деяких художників і арт-педагогів (наприклад, А. Хілла у Великобританії), які намагалися залучити пацієнтів різних лікувальних установ до занять образотворчим мистецтвом. 1960 - 1980-ті рр. виявилися вирішальними в становленні арт-терапевтичного напряму. Саме тоді були створені перші професійні об’єднання, які сприяли впровадженню і більш чіткому визначенню ролі арт-терапевтичних методів у різних областях практичної роботи.

Арт-терапія створює можливість як для занурення у хворобливі переживання, так і для актуалізації ресурсних станів, а також для трансформації та інтеграції досвіду Сучасне розуміння арт-терапії передбачає, по-перше, використання мови образотворчої експресії; по-друге, безпосередня участь людини в образотворчому процесі. Швидко зростаючий у нашій країні інтерес до різноманітних напрямів терапії творчістю, зокрема й арт-терапії, навряд чи можна цілком пояснити «екзотичністю» цих напрямків або «інформаційним голодуванням». Звісно ж, що найбільш значимими факторами інтересу $є$ орієнтація арт-терапії на властивий кожній людині внутрішній потенціал здоров'я і сили, iї акцент на природному прояві думок, почуттів і настроїв у творчості (Копитін, 2001).

Арт-терапія має очевидні переваги перед іншими - заснованими винятково на вербальній комунікації - формами психотерапевтичної роботи з психічною травмою. Нижче наведені деякі найбільш значимі з цих переваг.

1. Арт-терапія є засобом переважно невербального спілкування. Це робить iї особливо цінною для тих, хто відчуває складності в усвідомленні і вербалізації своїх переживань i їхньої «невираженості», що переживають особи 3 посттравматичним стресовим розладом. (Як відомо, травматичні спогади $є$ «застиглими» в певному відділі мозку, тому людина не сприймає їх як частину біографічного шляху, вони є надто жахливими і неприродними для психіки, тому їх дуже часто буває важко, а під час і неможливо, висловити за допомогою слів). Символічна мова є однією з основ образотворчого мистецтва, дозволяє людині часто більш точно висловити свої переживання, екологічно пропрацювати 
Арт-терапевтична підготовка як складова формування соціальної зрілості курсантів поліції

травматичний досвід. Зцілення від травми відбувається тоді, коли людина подумки повертається в травмуючу ситуацію, описує свої почуття і переживає іiі, але $з$ додаванням ресурсів.

2. Образотворча діяльність $є$ потужним засобом зближення людей, своєрідним «мостом» між психологом і клієнтом. Це особливо цінно в ситуаціях у спілкуванні з приводу занадто складного і делікатного предмета, у роботі 3 ПТСР та психічною травмою, де одними із симптомів $є$ підозрілість, утруднення в налагодженні міжособистісних контактів, небажання займатися терапією, торкатись болісних переживань.

3. Образотворча діяльність у багатьох випадках дозволяє обходити «цензуру свідомості», тому надає унікальну можливість для дослідження несвідомих процесів, вираження й актуалізації латентних ідей і станів, соціальних ролей і форм поведінки (Эдна Б. Фоа Кина \& Мэтью Дж. Фридман, 2005 , с. $124-125)$.

Результати дослідження. Агресивність - одне з найчастіших відхилень у поведінці злочинців. Нині розроблено програми й окремі заняття щодо зняття стану агресивності (Кулінка, 2011). Нами розроблена програма «Арттерапевтичний вплив на агресивну особистість». Вона передбачає 14 зустрічей 3 агресивними підлітками.

Кожне із занять проводять за певним сценарієм. Тривалість занять - 11,5 год. два рази на тиждень. Курсанти поліції, які проводять заняття, будують свою роботу на основі принципів довіри, збереження таємниці про те, що відбувається безпосередньо під час тренінгу.

Основна мета занять - навчати підлітків контролювати свою поведінку і впливати на неї.

На перших зустрічах формується довіра між учасниками заняття; на другому - вони вчаться вступати в контакт з іншими дітьми, які беруть участь у заняттях. На останньому - підлітки вчаться так будувати свою поведінку, щоб справлятися із ситуаціями, які приводять до агресії.

Середня частина програми спрямована на визначення, вербалізацію й активізацію особистих стандартів. Тут визначаються норми поведінки, пов'язані 3 доброзичливістю, і відбувається навчання стримування агресії. Діти вчаться зіставляти особистісні норми 3 власною поведінкою. Звичайно, такі заняття викликають бажання працювати над собою.

В останній частині програми передбачається навчання різних технік самоконтролю та прогресивної поведінки в ситуаціях, що спричинюють агресію.

На першому занятті основною метою є формування почуття безпечності.

Професіоналізм педагога: теоретичні й методичні аспекти. - Вип. 11. - Слов'янськ, 2019. 
Основні вправи: Вправа «Групове інтерв'ю». По черзі кожний відповідає на деякі питання. Для того щоб активізувати гру, ведучий кидає тому, хто запитує, м'ячик чи будь-яку легеньку іграшку. Запитання можуть бути такого типу: «Твій улюблений колір», «Твої улюблені фрукти», «Куди ти любиш ходити під час канікул?», «Чим любиш займатися в неділю?», «Твій улюблений урок», «Що тебе більше всього радує?», «Що найбільше засмучує тебе?», «Чи є в тебе друг?», «Через що ти сумуєш?», «Твоя улюблена пісня».

Вправа «Гордіїв вузол». Учасники стають у коло, заплющують очі й витягують перед собою руки. За сигналом кожний має піймати руки будь-кого 3 партнерів. Потім ведучий призначає гравця, який починає розплутувати цей вузол.

Основна мета другого заняття - завоювання довіри.

Вправа «Хто любить». Усі сидять на стільцях чи стоять у намальованих на підлозі колах. Одному з учасників немає місця і він, проходячи між стільцями, запитує: «Хто любить фруктове морозиво?». Ті, хто відповідають ствердно, встають і звільняють стільці, а потім, залишившись без місця, запитують те саме.

Гра в парах «Сліпий веде кульгавого». Учасникові А надягають на очі пов'язку. Учасник Б шкутильгає. А веде Б за певним маршрутом із різними перешкодами (стільці, книжки тощо). Кульгавий підказує сліпому, який його підтримує. За порушення правил руху та втрату рівноваги пара дістає штрафне очко. Перед кожною парою міняють перешкоди. Після завершення гри учасники обговорюють іiі результати. Партнери інформують, яка поведінка допомогла їм подолати труднощі. (Наприклад, мені допомогли твої ...). При цьому вони звертаються безпосередньо один до одного.

Мета третього заняття - обмінятися позитивною інформацією, провести тренування концентрації на собі та на інших.

Вправа «Разом можна більше». Кожен з учасників вибирає собі місце. Стоять прямо, п’ятки разом, носки нарізно. Не відриваючи ніг від підлоги, робити нахили в різних напрямках. Кожен перевіряє, як далеко він може нахилитися, не впавши при цьому. Після цього учасники сідають у певному місці. Ведучий пропонує обговорити цю вправу. Він ставить уточнюючі запитання типу: «Ти можеш описати, що відчував, виконуючи цю вправу?» Після цього учасники поділяються на пари і намагаються повторити цю вправу, підбадьорюючи та підтримуючи один одного. Виконавши вправу, підлітки обговорюють іiі, їм ставлять запитання типу: «У якому випадку тобі вдалося нахилитися далі?», «Чому?», «Що ти відчував, коли поруч був друг?», «Чи можеш порівняти свої почуття після виконання першої і другої вправи?», «Що ти хочеш сказати своєму партнерові?» (подякувати, оцінити його допомогу 
Арт-терапевтична підготовка як складова формування соціальної зрілості курсантів поліції

тощо). Ведучий активно бере участь у грі, щоб допомагати учасникам у ході дискусії.

Вправа «Похвальна грамота». Діти дістають картки за кількістю учасників занять. На кожній записано два незакінчених речення: «Я ціню в тобі ...», «Мені подобається, як ти ...» Учасники на свій розсуд закінчують речення і віддають адресату. У результаті ведучий разом із дітьми робить висновок, що кожна людина має позитивні риси, однак говорити про них значно важче, ніж критикувати і насміхатися. Ведучий висловлює надію, що учасники відшукають позитивні риси у своїх друзів і скажуть їм про це.

Мета четвертого заняття - усвідомлення емоційного життя, концентрація на собі, почуттєва сприйнятливість.

Вправа «Що це означає». Учасникам пропонують таблицю, на якій написано назви почуттів: задоволення, невдоволення, злість; утома, здивування, сором; радість, полегшення; гнів, нетерпимість, прикрість.

Ведучий пропонує пояснити, як діти розуміють слова, що позначають почуття. Потім вони зображують одне з почуттів за вибором у статичній позі (пам'ятник) чи в русі. Ведучий разом із дітьми намагається відгадати, яке почуття зображено.

П’яте заняття ставить за мету активізувати знання учасників про моральні норми.

Етюд «Яка норма». Учасників розподіляють на дві групи. Кожна отримує аркуш, на якому описано ситуацію, яку треба інсценувати. Завдання глядачів визначити норму, що іiї порушив герой. Орієнтовні ситуації:

a) Сашко, учень 11 кл. повертався зі школи додому. На вулиці до нього почали чіплятися хлопці, старші за нього. Вимагали гроші. Сашко дуже злякався, але грошей не дав. Тоді вони побили його і забрали гроші;

б) хлопці із 7 кл. хотіли після уроків пограти в м'яча, але майданчик зайняли восьмикласники. Скільки їх не просили, вони не пішли з поля. Тоді семикласники почали їм заважати, кидати в них каміння. I почалася бійка.

Бесіда присвячується обговоренню цих етюдів. Ведучий запитує, чи можна всіх їх об’єднати загальною формулою: «Не роби лиха ближньому». Він пропонує навести приклади поведінки, що свідчать про порушення норм. Конкретизуючи, ця норма може бути такою: не бий, не вистежуй, не псуй чужих речей, не набридай. Конкретні норми записують.

Мета шостого заняття - активізувати чуттєве сприйняття заборони. Передбачення наслідків агресивної поведінки.

Інсиенування «Суд». Жеребкуванням визначають ролі в грі: прокурора, захисника, присяжних, звинувачуваного, потерпілих, експерта та ін. Ведучий

Професіоналізм педагога: теоретичні й методичні аспекти. - Вип. 11. - Слов'янськ, 2019. 
Арт-терапевтична підготовка як складова формування соціальної зрілості курсантів поліції

грає роль судді, який ознайомлює дітей із принципами проведення суду. Засідання ведуть суддя, прокурор і захисник, який має право виступити 3 промовою. Для різноманітності учасники після проведення одного засідання можуть помінятися ролями.

Наведемо приклади сценаріїв пригод.

a) Миколці 12 років. Його постійно ображав однокласник, розповсюджував про нього плітки, обзивав. Миколка довго терпів образи. Але поступово гнів його зростав. Одного разу він прийшов у квартиру до свого кривдника, таємно вкрав його кота і кинув під машину;

б) Вітя із 7 кл приїздив до школи на велосипеді, який залишив у гардеробі. Хтось продірявив йому камеру. Друзі сказали, що це зробив Петро. Вітя побив його.

На сьомому занятті - тренування сприйняття норми, підготовка до обговорювання ситуацій, що провокують агресію.

Сюжет. Усі розподіляються на 4 групи, кожна отримує аркуш із темою складеної розповіді, але з протилежними завданнями.

Тема сюжету: Миколка побив товариша після контрольної роботи 3 математики. Завдання для I групи: скласти сюжет до підтеми «Що зробив Миколка після контрольної роботи?»; друга тема - «Що зробив товариш під час контрольної роботи та після неї?»; третя - «Що Миколка хотів від свого товариша?»; четверта - «Що Миколка відчував?»

Після закінчення роботи в групах читають уголос складені сюжети, а потім готують інсценування: вибирають акторів, режисера, оповідача. Актори описують події і показують відповідну поведінку. Оповідач розповідає про емоції героїв, коли, наприклад, один із них говорить, що хоче списати. Ведучий стежить за чіткістю словесного описування.

Після цього відбувається обговорення, оцінювання поведінки Миколи, його товариша й загальновизнаних норм. Учасники розташовуються на підлозі й намагаються відтворити у своїй уяві цей випадок. Через деякий час ведучий пропонує скласти подумки свою оцінку поведінки Миколки. Про неї можна сказати іншим або записати на папері. Ведучий прагне, щоб кожний висловив свою думку, не боявся, що його розкритикують.

Мета восьмого - дев'ятого занять - формування особистої проблеми.

Інсиенування «Театр тіней». За бажанням один 3 учасників стає режисером театру, який розіграв подію, що справді мала місце в його житті і завершилась агресивною поведінкою. Він розподіляє ролі серед інших учасників, зокрема ролі «думки» і «почуттів». Друга акторська група - «тіні» одночасно розігрують такни самий інцидент, але в постулативній формі 3 
Арт-терапевтична підготовка як складова формування соціальної зрілості курсантів поліції

відповідною модифікацією поведінки героя (його думки, реакції) під керівництвом того самого режисера. Обговорення інсценування.

Вправа на уяву «Я режисер власного життя». Учасники лягають на підлогу й закривають очі. По команді ведучого діти уявляють найбільш вірогідну ситуацію, що спричинює агресивну поведінку. Однак зараз вони вже самі режисери свого життя, можуть запроєктувати свої думки, поведінку в той момент, коли вони гніваються. Те, що відбудеться в цій ситуації, залежить від них самих. Після завершення гри ведучий пропонує, щоб діти розповіли один одному про свою поведінку.

Гра «Пункт прокату ідей». Учасники сидять у колі. Ведучий пропонує згадати ситуацію, коли вони поводилися агресивно, але й досі не уявляють собі, як можна було поводитися інакше. Зараз у них з'явилася можливість позичити в когось ідею розв'язання цього питання. Особа, яка хоче позичити ідею, розповідає про цей випадок, потім сідає перед обраним товаришем і говорить йому: «Не знаю, як можна було б зробити інакше в цій ситуації. Можна я позичу в тебе ідею?» 3 таким проханням він звертається до інших товаришів, поки не вирішить запозичити ідею. Ця гра подобається дітям найбільше.

Гра «Карта мого життя». Завдання полягає в тому, щоб накреслити карту «доріг свого життя». На ній має бути головний шлях, роздоріжжя, другорядні дороги, круті дороги, окружні, прямі, асфальтовані, вибоїсті, із перешкодами, об'їздами, зі стоянками, чудовими краєвидами тощо. Потім діти креслять трасу свого майбутнього життя. Порівнюють свої малюнки. Розбір досвіду.

На завершення циклу всіх занять ведеться розмова, під час якої учасники набувають нового досвіду й обговорюють його. Як бачимо, серед методів арттерапевтичної підготовки в запропонованому тренінгу використовувалися анімаційна терапія, тілесно-орієнтована терапія, ігротерапія та сторітеллінг (розповідання історій).

Висновки з дослідження і перспективи подальших розвідок у цьому напрямі. Професійна підготовка майбутніх поліцейських передбачає наявність сукупності загальних i професійних знань, які слід постійно оновлювати та поповнювати відповідно до змін законодавчої бази, досягнень науки, розвитку інформаційних ресурсів. Професійна підготовка в контексті модернізації освіти України реалізується через два види змін: організаційноструктурні й змістовно-технологічні. Нами розглянуто змістовнотехнологічний блок. Методологія кримінального профайлінгу передбачає роботу з матеріалами кримінального провадження та інтерпретацію доказів. Результатом роботи профайлера є кримінальний профіль - юридично значимий

Професіоналізм педагога: теоретичні й методичні аспекти. - Вип. 11. - Слов'янськ, 2019. 
Арт-терапевтична підготовка як складова формування соціальної зрілості курсантів поліції

документ, у якому описані особистість і поведінка злочинця та жертви в ключі вчиненого злочину або серії злочинів. Сучасна парадигма профайлінгу має кілька джерел походження: дослідження кримінологів, фахівців із галузі судової медицини, психіатрів і кримінальних психологів.

Арт-терапія створює можливість як для занурення у хворобливі переживання, так і для актуалізації ресурсних станів, а також для трансформації та інтеграції досвіду. Застосували арт-терапію засобом переважно невербального спілкування та через образотворчу діяльність. Подальшу роботу вбачаємо в розробці педагогічних умов застосування кримінального профайлінгу на заняттях у закладах вищої освіти.

\title{
СПИСОК ВИКОРИСТАНИХ ДЖЕРЕЛ
}

1. Кулінка, Ю. С. (2011). Формування готовності майбутніх педагогів до запобігання девіантній поведіниі підлітків: матеріали та методичні рекомендації до спецкурсу. Кривий Ріг, Україна: КДПУ.

2. Копітин, А. И. (2001). Практикум по арт-терапии. Санкт-Петербург, Российская Федерация: Питер.

3. Цільмак, О. М. (2011). Професіогенез компетентності фахівиів кримінальноӥ міліиії: теорія та практика: монографія. Одеса, Україна: РВВ ОДУВС.

4. Эдна Б. Фоа Кина, Теренс М. Кин і Мэтью Дж. Фридман. (2005). Эффективная терапия посттравматического стрессового расстройства. Москва, Российская Федерация: Когито-центр.

\section{ART-THERAPY TRAINING AS A COMPONENT OF DEVELOPING SOCIAL MATURITY OF POLICE STUDENTS}

\author{
Natalia Dumko \\ teacher, \\ Odesa State of the University of Internal Affairs \\ Odesa, Ukraine \\ ORCID ID 0000-00003-2044-4496 \\ ndumko@my.com
}

\begin{abstract}
The article deals with the issue of peculiarities of art-therapeutic training of future police officers for developing their social maturity, for justifying the basics of criminal profiling in their professional training. The professional training of future police officers implies the presence of a set of general and professional knowledge, which should be constantly updated and coordinated with changes in the legislative framework, scientific achievements, and development of information resources. The professional training in the context of modernization of education in Ukraine is realized through two types of changes: organizational, structural and content-technological. We have reviewed the content technology unit. Due to changes in the concept of policing and shifting its emphasis on the function of social services to the population, it is necessary to equip police officers with deep psychological and pedagogical knowledge related to interaction with the population and conflict resolution, methods of providing psychological assistance in interventions and family interventions.
\end{abstract}

(c) ДВНЗ «Донбаський державний педагогічний університет» 


\section{Н. ДУМКО}

Арт-терапевтична підготовка як складова формування соціальної зрілості курсантів поліції

The result of the work of the profiler is a criminal profile - a legally significant document that describes the identity and behavior of the offender and the victim in the key to the crime or series of crimes. The modern paradigm of profiling has several origins: the study of criminologists, forensic experts, psychiatrists and criminal psychologists.

Art therapy creates the opportunity for both immersion in painful experiences and for the actualization of resource states, as well as for the transformation and integration of experience. Art therapy is mainly applied through non-verbal communication and through visual activities. We see further work in the development of pedagogical conditions for the use of criminal profiling in higher education institutions. The exercises are introduced: "Group Interview", "Blind leads lame", "Gordian knot", "Loving", and others.

Key words: art therapy; criminal profiling; police cadet training; social maturity.

\section{REFERENCES}

1. Kulinka, Yu. S. (2011). Development of future teachers' readiness to prevent deviant behavior of teenagers: materials and guidelines for the special course. Kryvyi Rih: KDPU.

2. Kopytina, A. I. (Ed). (2001) Art therapy workshop. Sankt-Peterburg, the Russian Federation: Piter.

3. Tsilmak, O. M. (2011) Professional genesis of criminal police specialists: theory and practice: monograph. Odesa, Ukraine: RVV ODUVS.

4. Edna B. Foa Kina, Terens M. Kin, \& Metyu Dzh. Fridman. (2005) Effective therapy for post-traumatic stress disorder. Moscow, the Russian Federation: Kogito-centr.

Матеріали надійшли до редакції 30.10.2019 р. 